\title{
La libertad de expresión y el ejercicio de la Abogacía en España. Un caso paradigmático: la STC 113/2000, de 5 de mayo*
}

\author{
Francisco Javier Jiménez Lechuga \\ Profesor del Instituto Andaluz de Administración Pública
}

\begin{abstract}
«El hombre razonable se adapta al mundo y ocurre lo contrario con quien es irrazonable. De este último depende, pues, el progreso humano». Georges BERNARD SHAW, «Manual del revolucionario», en Una comedia y una filosofía, 1903.
\end{abstract}

SUMARIO: I. IDEAS GENERALES. II. LOS VALORES SUPERIORES DEL ORDENAMIENTO JURÍDICO. III. LOS DERECHOS FUNDAMENTALES EN LA CONSTITUCIÓN ESPAÑOLA DE 1978. IV. EL ESTATUTO JURÍDICO DE LA ABOGACÍA ESPAÑOLA. V. LA DOCTRINA DEL TRIBUNAL CONSTITUCIONAL EN EL CASO CONCRETO AL QUE SE ALUDE CON OCASIÓN DE LA PROBLEMÁTICA DEL BINOMIO LEGALIDAD-SUPRALEGALIDAD. VI. CONCLUSIONES.

\section{IDEAS GENERALES}

La convivencia social no es siempre fácil y las sociedades se dotan de normas que regulan la conducta del hombre y sus repercusiones, informado, en la mayor parte de los casos, por una sistemática axiológica bien definida que orienta la actuación de los individuos y de los poderes públi-

\footnotetext{
* Este texto - con las modificaciones, actualización y ampliación necesarias- constituye en esencia el contenido de la ponencia que tuve el gusto de presentar a unas Jornadas sobre el ejercicio de la Abogacía en España, organizadas en la primavera del año 2002 por el Ilustre Colegio de Abogados de Granada y que, a mi juicio, recoge un hecho cotidiano y esencial: el ejercicio de la Abogacía en nuestro país y las reglas por las que el mismo ha de regirse desde un punto de vista constitucional teniendo en cuenta, además, lo que se entiende por el ejercicio de las profesiones liberales (tituladas) en nuestra patria en estos tiempos convulsos y confusos en los que, sin embargo, hemos de vivir. Por esto - y porque me ha parecido que el asunto tenía cierta relación con la obra de un importante jurista español recientemente fallecido-, he creído conveniente contribuir con el mismo al esfuerzo que la Revista de Estudios de la Administración Local va a dedicar al profesor don Sebastián Martín-Retortillo Baquer — cariñoso e intimista recuerdo (quizás homenaje) - Ciertamente, la zaga de administrativistas que componen esta familia aragonesa (Cirilo, Sebastián y Lorenzo) ha aportado una cierta impronta al Derecho administrativo español y puede afirmarse que, en líneas generales, ha creado escuela. El lenguaje claro, castizo, austero y preciso de estos tres administrativistas - especialmente de Sebastián - ha sido destacado por algunos colegas y, modestamente, yo mismo lo he hecho en algún lugar que no citaré ahora.
} 
cos en un sentido determinado y no en otro. Hoy, dada la complejidad que la organización social ha alcanzado en todos los países occidentales, esa dialéctica y retórica grandilocuentes han entrado en crisis y la orfandad de valores que el mundo occidental padece amenaza con convertirse en una de las principales causas de desintegración del tejido social destinado a asumir esa escala de valores a que se refería hace más de medio siglo Th. Adorno, propiciando con ello un estado individual o social de perplejidad y confusión muy acentuados. Este cambio, esta diferencia generacional, es patente. Por eso, el ciudadano se encuentra hoy casi totalmente perdido en un mundo como el nuestro. Frente a un Estado de Bienestar en el que la saturación informativa es clara, apoyada incluso con los modernos medios informáticos que los individuos poseen, hacen posible, en cambio, que el hombre viva sólo - sobre todo en las grandes urbes- y que la pérdida de identidad sea casi completa, sin que tampoco le sea de utilidad la telemática, las modernas comunicaciones y los medios de transporte de que el mundo actualmente está dotado. Todo cuanto antecede, que no es más que la constatación de un fenómeno social incuestionable (también negativo en mi opinión), hunde al ciudadano en un estado de postración frente a sí mismo, la sociedad y el propio Estado. Sólo una «oligarquía intelectual» o una élite tienen la posibilidad de escapar a esta alienación o «cosificación» de que hablan los alemanes. Y el problema (los males apuntados que aquejan a las sociedades occidentales en su conjunto) se agrava sobremanera ante la desilusión y el «fiasco» que ha supuesto el desarrollo político y económico de estas modernas sociedades, dominadas por una oligarquía económica, que ha hecho de las mismas (cuerpo social) algo fácilmente manejable y dirigible y, lo que es peor todavía, ha

\footnotetext{
El profesor don Sebastián Martín-Retortillo BaQuer, recientemente fallecido como ya he dicho (en octubre de 2002), ostenta el mérito - aunque no exclusivamente- de la introducción en España del gusto por el estudio del Derecho administrativo económico, recogiendo la doctrina alemana (Forsthoff, BACHOF, WolfF, StOBER) y estudiando aspectos de nuestra disciplina que no todos han tenido el acierto de exponer con la brillantez que le caracterizaba. Así, recuerdo ahora solamente y a título meramente orientativo aportaciones tales como las de los títulos Descentralización administrativa y organización política, El reto de una Administración racionalizada, La defensa en Derecho del Estado, La evolución histórica del régimen foral navarro, Parlamento y Gobierno en la planificación económica, Pasado, presente y futuro de las Comunidades Autónomas y Perspectivas de la Administración pública, entre otras muchas. Por esto, he creído obligada mi participación modesta y alicorta, pero sentida, que la REAL rinde al profesor aragonés recientemente fallecido y lo hago con la exposición de este caso jurisprudencial que aborda, desde el punto de vista del ejercicio de las profesiones liberales, el respeto al derecho fundamental de la libertad de expresión. Por eso también puede sorprender esta interrogante: ¿gozan los Abogados del Estado de igual derecho que el resto de los profesionales? No es este un asunto que el profesor homenajeado estudie en su libro sobre los Abogados del Estado. Pero - y esto es muy discutido en Francia y Alemania—, no parece que el Estado tenga per se (intuitu personae) atribuidos algunos derechos fundamentales o pueda ser sujeto acreedor o titular de los mismos. No entraré, empero, a considerar esta cuestión en este lugar. Hay que felicitar a la REAL por el acierto en la decisión tomada.
} 
LA LIBERTAD DE EXPRESIÓN Y EL EJERCICIO DE LA ABOGACÍA EN ESPAÑA. UN CASO PARADIGMÁTICO...

transformado dictaduras militares de todo signo en dictaduras formales («democracias parlamentarias» si se quiere) ${ }^{1}$.

No parece ciertamente posible hacer aquí un estudio pormenorizado de la evolución histórica de los derechos fundamentales, tal y como los recogen las Constituciones de los países de nuestro entorno, aunque sí resulta interesante conocer algo los fundamentos filosóficos de los derechos humanos $^{2}$, la declaración de derechos y libertades ${ }^{3}$, los derechos económicos, sociales y culturales ${ }^{4}$ y el fenómeno de la internacionalización de los derechos humanos 5 .

Sobre lo primero - la fundamentación filosófica de los derechos humanos-, ha escrito algún autor recientemente que en los siglos XVI y XVII (por no remontarse más lejos) se produce una decisiva transposición al plano de la subjetividad de los postulados de la ley natural, configurándose una amplia teoría de los derechos naturales en relación sobre todo con el descubrimiento de América y la aportación de la Escuela española de Derecho Natural, con especiales aportaciones a estas tesis del Padre Suárez, Ginés de Sepúlveda y Gabriel Vázquez de Menchaca. Con Locke la defensa de los derechos naturales a la vida, la libertad y la propiedad se convierte en el fin prioritario de la sociedad civil y en el principio legitimador básico del Gobierno. Mientras que PuFENDORF cifró en la dignidad humana el postulado del que se deriva su sistema de derechos naturales ${ }^{6}$. Y con Rousseau se concibió la formulación más célebre de la teoría del contrato social, para justificar mediante ella toda forma de poder en el libre consentimiento de los miembros de la sociedad. Para E. Kant, todos los derechos naturales se compendian en el derecho a la libertad, en cuanto

\footnotetext{
1 J. ORTega y Gasset, La rebelión de las masas, Madrid, 1933: D. Hume, De la Moral y otros escritos, CEC, Madrid, 1982; A. Perrot, Principios jurídicos y positivismo jurídico, Buenos Aires, 1970; J. Ortega y Gasset, «¿Qué son los valores?, en Obras Completas, Alianza Editorial, Madrid, 1983; Giuseppe Marchello, Dai besigni ai valori, Nuovi studi sull'etica dei valori, Giappicheli, Turín, 1977; E. Díaz, Socialismo en España. El partido y el Estado, Mezquita, Madrid, 1982 y A.E. PÉrez LuÑo, Derechos humanos, Estado de Derecho y Constitución, Ed. Tecnos, Madrid, 1984.

2 J.L. CASCAJo, La lucha por el Estado de Derecho, Sistema, 1977.

3 J. García Torres, A. Jiménez Blanco, Derechos fundamentales y relaciones entre particulares, Ed. Civitas, Madrid, 1986.

${ }^{4}$ G. Peces-Barba Martínez, Tránsito a la modernidad y derechos fundamentales, Mezquita, 1982.

${ }^{5}$ A. Truyol Serra, Los derechos humanos, Ed. Tecnos, Madrid, 1984 y J. Ruiz Giménez, El Concilio Vaticano II y los derechos del hombre, Edicusa, Madrid, 1968.
}

${ }^{6}$ A.E. Pérez LuÑo, Los derechos fundamentales, Ed. Tecnos, Madrid, 1988. 
ésta puede coexistir con la libertad de los demás según una ley universal correspondiendo, por tanto, tal derecho a cada hombre en base a su propia humanidad. Poco más tarde se empieza ya a hablar de los derechos huma$\operatorname{nos}^{7}$, positivizándose muchos de estos derechos como fundamentales aunque con un significado más simbólico que real según es conocido. La Declaración de Derechos del Hombre y del Ciudadano de 1789 pasó a incorporarse a la Constitución francesa de 1791 continuando con la Constitución española de 1812, la belga de 1831, la de 1876 y la de la II República española de 1931. También la Declaración de la libertad de 1848 resalta especialmente el principio igualitario. Afirma A.E. Pérez LuÑo ${ }^{8}$ que la impronta del Manifiesto se refleja con nitidez en la Declaración de los Derechos del Pueblo Trabajador explotado, promulgado en la URSS, tras el triunfo de la Revolución, en el año 1918, y cuyo texto redactado por Lenin se incorporó a la Constitución soviética de ese mismo año, como réplica a las declaraciones burguesas de derechos. Esta Declaración ignoraba el reconocimiento de cualquier derecho individual; sin embargo, la Constitución soviética de 1936 incluyó una tabla de derechos políticos, cuya titularidad jurídica no queda restringida a los trabajadores, sino que se extiende a todos los ciudadanos de la URSS, si bien su ejercicio tiene siempre como límite el interés de la colectividad. Este texto ha inspirado el estatuto constitucional de los derechos fundamentales no sólo en la URSS, sino en la mayor parte de los países socialistas ${ }^{9}$. Los hitos constitucionales posteriores y más importantes vienen representados por la Constitución mexicana de 1917, la Constitución de Weimar de 1919, la Ley Fundamental de Bonn de 1949, la italiana de 1947, la española de 1978 y la portuguesa de $1976^{10}$.

Como ha puesto de relieve la doctrina española, en nuestro siglo se han producido una serie de acontecimientos trágicos, y gravemente lesivos para la causa de las libertades, que han potenciado el esfuerzo de los hombres y de las naciones para la protección de los derechos humanos. Así, las Naciones Unidas, haciéndose eco, desde los primeros momentos de su trayectoria de estas apremiantes exigencias, promulgaron en el año 1948 la Declaración Universal de los Derechos Humanos, a la que siguieron los Pactos Internacionales de Derechos Civiles y Políticos, y Derechos Económicos, Sociales y Culturales de 1966. En el seno del Consejo de Euro-

\footnotetext{
7 Th. PAINE, The Rights of Man, 1792.

8 A.E. Pérez Luño, Los derechos fundamentales, Ed. Tecnos, Madrid, 1988.

${ }^{9}$ No se olvide el significado que tiene la caída del muro de Berlín en 1989.

${ }^{10}$ Posteriormente modificada en varias ocasiones.
} 
pa se firmó en 1950 el Convenio para la Protección de los Derechos Humanos y de las Libertades Fundamentales, equivalente en el ámbito europeo al Pacto de los Derechos Civiles y Políticos de la ONU, posteriormente completado con la Carta Social Europea, suscrita en Turín en el año 1961, que corresponde al Pacto de Derechos Económicos, Sociales y Culturales de las Naciones Unidas. Una curiosa polémica se suscitó en Europa hace unos años sobre si la Unión Europea respetaba o no los derechos fundamentales de sus ciudadanos y, en particular, si ello ocurría a los alemanes respecto del resto de los europeos. En 1974 el Bundesverfassungsgerichtshof en una célebre sentencia entendió que no, razón por la cual habría de aplicarse el Derecho alemán cuando el europeo no ofreciese esas garantías. El Tribunal de Luxemburgo pronto arrambló con estas tesis y el propio Tribunal Constitucional alemán en 1986 entendió que el Derecho comunitario europeo garantizaba plenamente a los alemanes el disfrute de los derechos fundamentales que en su país le eran reconocidos. Esta polémica, sin embargo, no tiene ahora interés a los efectos que nos ocupan ${ }^{11}$.

Y, aunque los derechos humanos y los derechos fundamentales son utilizados en muchas ocasiones por la doctrina como sinónimos (Sinnverwandtsworten), han existido tendencias que explicaban las diferencias existentes, entendiendo que estos últimos son derechos positivos a nivel interno, mientras que los derechos humanos vendrían a ser los derechos naturales positivizados en las declaraciones y convenciones internacionales, así como a aquellas exigencias básicas relacionadas con la dignidad, libertad e igualdad de las personas que no han alcanzado un estatuto jurídico positivo ${ }^{12}$. En este orden de cosas, me parece, con A.E. Pérez LuÑo, que los derechos humanos aparecen como un concepto de contornos más amplios e imprecisos que la noción de derechos fundamentales ${ }^{13}$, porque los primeros suelen venir entendidos como un conjunto de facultades e instituciones que, en cada momento histórico ${ }^{14}$, concretan las exigencias de la dignidad, la libertad y la igualdad humanas, las cuales deben ser reconocidas positivamente por los ordenamientos jurídicos a nivel nacional e internacional. Se tiende a afirmar también que por derechos fundamentales se entienden aquellos derechos humanos garantizados por el ordenamiento jurídico positivo, en la mayor parte de los casos en la nor-

\footnotetext{
${ }^{11}$ Vid. STC alemán Solange I y Solange II.

${ }^{12}$ La distinción, empero, no me parece convincente.

${ }^{13}$ A.E. Pérez LuÑo, op. cit.

${ }^{14}$ A. GIL-RoBLEs, «El origen histórico de los derechos humanos: comentario de una polémica», RFDUC, 1979.
} 
mativa constitucional ${ }^{15}$, y que suelen gozar de una tutela reforzada como se sabe ${ }^{16}$.

Interesa dejar anotado aquí brevemente que el significado de la fórmula del artículo 1.1 C.E., contemplado desde varias perspectivas, añade matices nuevos y enriquecedores que están muy próximos -incluso lo superan, diría yo- a la concepción alemana. Y, en efecto, ambos adjetivos («social» y «democrático») no sólo suman y se superponen, sino que se multiplican. Ha afirmado ya hace algunos años A. Garrorena Morales que la primera de esas posibilidades de interpretación concurrente se produce en el terreno de la interacción de los diversos momentos que integran sintácticamente aquella unidad. Quiere decirse que cada adjetivo, flanqueado en el interior de la fórmula de referencia por los otros dos, queda afectado, modificado por ellos en su sustancia, hasta adquirir matices y posibilidades que jamás hubiese adquirido en solitario; de ahí que la resultante de dicha fórmula no sea exactamente igual a la suma de significado de sus sumandos, sino que quede prolongada por esa adición de sentido que se desprende de la mutua implicación en que tales términos se encuentran ${ }^{17}$.

\section{LOS VALORES SUPERIORES DEL ORDENAMIENTO JURÍDICO}

Puede ya colegirse fácilmente de lo que venimos afirmando que no es lo mismo conceptualmente estos valores superiores del ordenamiento jurídico que los derechos fundamentales y libertades públicas que están constitucionalmente garantizados en su ejercicio. Una lectura atenta de nuestra Constitución muestra todo esto bien a las claras. También se ha apuntado ya algo sobre el particular en el apartado anterior. Para un sector importante de la doctrina española, además de comprender los contenidos en la fórmula del artículo 1.1

\footnotetext{
${ }^{15}$ AA.VV., IV Jornadas de Profesores de Derecho Internacional y Relaciones Internacionales, Universidad de Granada, 1980; J. LALIN DE ABADI, et alli, Estudios sobre la Constitución española de 1978, Zaragoza, 1979; J. JiMÉNEZ CAMPO, «La igualdad jurídica como límite frente al legislador», REDC 9/1983; L. LóPEz GuerRA, «Las dimensiones del Estado social de Derecho», Sistema núms. 38-39/1980; AA.VV., Comentarios a la Constitución española de 1978, Edersa, Madrid, 1983; Wolfgang ABondroth, Sociedad antagónica y democracia política, Barcelona, 1973: WERNER KägI, Demokratie und Rechstaat, 1953: J. Cazorla Pérez, J.J. Ruiz-Rico Lendínez y M. BonaCHELA, Derecho, instituciones y poderes en la Constitución de 1978, Granada, 1983 y P. BARCELlona y G. CoRTuri, Stato e giuristi, Bari, 1971.

16 T. QUADRA-SALCEDO, El recurso de amparo y los derechos fundamentales en las relaciones entre particulares, Ed. Civitas, Madrid, 1981.

${ }^{17}$ A. Garrorena Morales, El Estado español como Estado social y democrático de Derecho, Ed. Tecnos, Madrid, 1991.
} 
C.E. (libertad, justicia, igualdad y pluralismo político), estos valores superiores tienen carácter vinculante para todos los poderes públicos y también entre particulares, al igual que ocurre con los derechos fundamentales. Se dice que corresponde a los tribunales la obligación de preservar esta norma básica material, norma básica sobre normas. Y esta obligación de desarrollar los valores superiores no corresponde sólo a los tribunales, sino a todos los productores de normas (Poder Legislativo, Poder Ejecutivo) — ambos del Estado o de las CC.AA. - así como a jueces, otros operadores jurídicos e incluso ciudadanos cuando crean normas por delegación de los productores ordinarios (el caso de los contratos o de los testamentos, por ejemplo). Y se destaca, en consecuencia, el carácter normativo de tales valores superiores y las consecuencias que de todo ello se derivan en la práctica ${ }^{18}$.

Por todo ello, como se comprende, los valores superiores del ordenamiento jurídico como auténticos derechos pueden invocarse y tienen, por así decirlo, fuerza normativa. Así lo entiende una parte de la doctrina 19 que opina que de su situación dentro de la Constitución se desprende que estamos ante una auténtica norma jurídica, aunque la positivización de los valores no los agote y quede una moralidad crítica ${ }^{20}$ no positivizada que

\footnotetext{
${ }^{18}$ A. Garrorena Morales, El Estado español como Estado social y democrático de Derecho, Ed. Tecnos, Madrid, 1991. G. Peces-Barba Martínez, Los valores superiores, Ed. Tecnos, Madrid, 1986. Tales características son: a) reconstruyen la teoría material de la justicia, sin necesidad de sostener posiciones iusnaturalistas (aunque algunos queridos colegas que hacen postulados o, mejor dicho, apostolado, iusnaturalista verán un planteamiento iusnaturalista implícito en esta posición que se sostiene), b) insertan la Constitución material en la concepción democrática del Derecho y del Estado, superando versiones de aquélla de corte totalitario, c) integran la perspectiva material que representa con la perspectiva formal, propia del normativismo, como se comprueba con el análisis de la norma básica de la Constitución con sus dimensiones formales — soberanía popular y Estado de Derechoy con sus dimensiones materiales - valores superiores-, d) son la norma básica material sobre normas y criterio de todas las normas del ordenamiento, e) refuerzan la tesis de separar, diriamos que la dificultad de la tesis de separar creación e interpretación del Derecho, puesto que afectan y sirven a ambas actividades. Así, son informadores, como base de las decisiones constitucionales fundamentales, de todo el desarrollo del ordenamiento (ya en la propia Constitución se inicia su desarrollo con el resto de las normas constitucionales). Son también criterio de interpretación para los operadores jurídicos (interpretación que se debe integrar con el resto de la Constitución, que es interpretación auténtica del legislador constituyente sobre lo que significan los valores superiores), y, f) son límite al poder, con lo que refuerzan el sometimiento y el control del poder al Derecho con su perspectiva material.

Una última reflexión se desprende de estas últimas consideraciones en opinión del autor referido y es la relación de norma básica de la Constitución, con la reforma de la misma. Afirma este autor que la inclusión del artículo 1.1 C.E., es decir, la norma básica material, introduce nuevos criterios en este tema de gran importancia, al que se refieren, entre otros, Carl Schmitt, Forsthof y Onida.

${ }^{19}$ G., Peces-Barba Martínez, Los valores superiores, Ed. Tecnos, Madrid, 1986.

${ }^{20}$ N. M. ${ }^{a}$ LóPez CALera, Hegel y los derechos humanos, Universidad de Granada, 1971 y AA.VV., Estudios de Filosofía del Derecho y Ciencia Jurídica en memoria y homenaje a Luis Legaz Lacambra, CEC, Madrid, 1983.
} 
presiona sobre los valores como Derecho positivo para enriquecerlos y complementarlos con una progresiva positivización de los valores superiores por el legislador, el juez, el resto de los operadores jurídicos e incluso los ciudadanos. Y el propio G. Peces-BArba afirma que en cuanto a la intensidad de la norma del artículo 1.1 C.E. se trata de una norma que señala los límites a alcanzar, que deja a los operadores jurídicos la elección de los cauces más adecuados para su efectividad, aunque ya en la propia Constitución se concretan algunos de esos cauces a través de los derechos fundamentales y a través de la organización de los poderes. Afirma también que no es de aplicación para su identificación la distinción entre normas categóricas y normas hipotéticas ${ }^{21}$. Desde el punto de vista del papel que desempeña en el ordenamiento jurídico, es norma de segunda instancia, metanorma, como dice Bоввіо, que tiene como función regular aquellos particulares actos humanos que son los actos productores de normas. Y no es una norma secundaria cualquiera, sino la norma secundaria material básica. Es, como decía ZitelmanN, «Derecho sobre el Derecho». Algún autor ha visto los rasgos que caracterizan a los derechos humanos y a los valores superiores del ordenamiento jurídico —en expresión de la Constitución española de 27 de diciembre de 1978- y que, en síntesis, serían los siguientes ${ }^{22}$ : a) presuponen la existencia de otras reglas y se refieren a ellas, o prevén la posibilidad de regulaciones jurídicas por normas futuras y se refieren también a ellas, b) sus destinatarios son aquellos que tienen que utilizar aquellas reglas o aquellos que tienen que crearlas ex novo, y, c) proporcionan una guía acerca de cómo y cuándo han de usarse las reglas sobre las que versan, qué alcance darlas, cómo combinarlas, cuándo otorgar preferencia (precedencia) a algunas de ellas, produciendo, pues, una guía para la producción de nuevas reglas ${ }^{23}$.

La importancia de la formulación de los valores superiores del ordenamiento jurídico que recoge el artículo 1.1 C.E. viene refrendada por las notas que algún sector doctrinal ha encontrado acertadamente y que comparto en su totalidad ${ }^{24}$. Desde un punto de vista político social, esto se ha

\footnotetext{
${ }^{21}$ En este sentido Norberto BoвbIo.

${ }^{22}$ A. Perrot, Principios jurídicos y positivismo jurídico, Buenos Aires, 1970. En igual sentido puede verse el estudio de CARRIó sobre el asunto.

${ }^{23}$ G. Peces-Barba Martínez, op. cit.

${ }^{24}$ G. Peces-Barba Martínez, Valores superiores, Ed. Tecnos, Madrid, 1986. En efecto, afirma que de lo expuesto se desprenden las siguientes dimensiones: a) Reconstruyen la teoría material de la justicia, sin nesidad de sostener posiciones iusnaturalistas (aunque algunos queridos colegas que hacen apostolado iusnaturalista verían un postulado o planteamiento iusnaturalista implícito en esta posición que sostengo), b) Insertan la Constitución material en la concepción democrática del Estado y del Derecho, superando versiones anteriores de aquella de corte totalitario, c) Integran la
} 
plasmado gracias al consenso alcanzado durante la tramitación del proyecto de Constitución española y que ha destacado el profesor E. Díaz, ya que ello es expresión de una preferencia social (su consecución) oracional basada en la realidad, en la experiencia que proporciona la Historia de España desde el prisma de esa ideología democrática, comunicada y aceptada por la mayoría. Se ve, pues, claramente, que los derechos humanos y los valores superiores son los derechos fundamentales positivizados. Esta afirmación, empero, no agota la distinción a fuer de simplista, porque cabría afirmar de todo lo expuesto que los valores superiores, positivados o no, deben servir de guía a la conducta humana.

\section{LOS DERECHOS FUNDAMENTALES EN LA CONSTITUCIÓN ESPAÑOLA DE 1978}

Debe haber quedado ya bien claro que los derechos humanos y los derechos fundamentales y libertades públicas no son lo mismo, esto es, que no son estos últimos los derechos fundamentales concretizados y positivizados; por el contrario, los derechos humanos son unos principios éticos y morales cuyo contenido esencial no puede, en modo alguno, recoger el Derecho positivo porque son inaprensibles para éste. Así lo entendía J.L. LÓPEZ ARANGUREn en sus lecciones de Ética y Moral y así los concibo yo mismo que sobre estos asuntos traté hace algunos años con el profesor Aranguren. Así también ha entendido la cuestión el profesor italiano Giorgio DEL VECCHIO desde unas coordenadas estrictamente cristianas. Y es precisamente por esa razón por la cual todas las Declaraciones Universales de Derechos del Hombre no han podido ser materializadas. Sólo en países avanzados (con la rémora del neocapitalismo, por supuesto) han conseguido plasmarse e informar la práctica social diaria siendo el resultado práctico obtenido hasta el momento muy modesto. Y es evidente, por lo demás, que no podría ser de otra manera. No puede exigirse más, ya que

perspectiva material que representa con la perspectiva formal, propia del normativismo, como se comprueba con el análisis de la norma básica de la Constitución con sus dimensiones formales — soberanía popular y Estado de Derecho-, y con sus dimensiones materiales — valores superiores-, d) Son la norma básica material sobre normas y criterio de todas las normas del ordenamiento, e) Refuerzan la tesis de la dificultad de separar creación e interpretación del Derecho, puesto que afectan y sirven a ambas actividades. Así, son informadores, como base de las decisiones constitucionales fundamentales, de todo el desarrollo del ordenamiento (ya en la propia Constitución se inicia su desarrollo con el resto de las normas constitucionales). Son también criterios de interpretación para los operadores jurídicos (interpretación que se debe integrar con el resto de la Constitución, que es interpretación auténtica del legislador constituyente sobre lo que significan los valores superiores), y, j) Son límite al Poder, con lo que refuerzan el control y el sometimiento del Poder al Derecho con su perspectiva material. 
lo que tienen de inmanente e impracticable los hace difícilmente aptos para ser recogidos —ni siquiera en su esencia, naturalmente- por los vigentes ordenamientos jurídicos de los países de nuestro entorno. Ese valor axiológico, subjetiva y objetivamente considerado —-moral y jurídico- hace que no puedan los derechos humanos alcanzar su plenitud en su sociedad avanzada - menos todavía en sociedades primitivas- por cuanto su posibilidad de garantía práctica es mínima — dada su naturaleza— salvo en lo que pudiéramos llamar el núcleo esencial de los mismos. Entrar en mayores precisiones en este lugar resulta imposible ${ }^{25}$ pero la doctrina se ha ocupado ampliamente de estos asuntos.

Hay que tener en cuenta, no obstante, que los derechos fundamentales son aquellos que recoge la Constitución en sus artículos 14 a 30.2 aunque, para nosotros, también lo son los demás hasta el 33, con la sola diferencia de que el procedimiento preferente y sumario no le es aplicable a la defensa de estos últimos (art. 53.2 C.E.). Algún sector de la doctrina discrepa de esta opinión nuestra y clasifica la configuración de los derechos fundamentales en valores superiores del ordenamiento jurídico que ya conocemos, principios constitucionales (art. 9.2 C.E. y otros), cláusulas generales (arts. 17.4, 18.4, 20.3, 24,2, 28.2 y 29 C.E.) y normas específicas o casuísticas (arts. 14 y 26 C.E.) así como normas de tutela (arts. 53 y 54 C.E.). Para A.E. Pérez LuÑo, es errónea la hermenéutica restrictiva de los derechos fundamentales en lo que se refiere a su vinculatoriedad reconocidos en el Capítulo II, o sea, los comprendidos en los artículos 14 a 38, de forma que quedaran excluidos de tal principio de sujeción los derechos reconocidos en el Capítulo III (arts. 39 a 52) como «principios rectores de la política social y económica». En este punto, el texto constitucional es tajante cuando señala que «El reconocimiento, el respeto y la protección de los derechos reconocidos en el Capítulo III informará la legislación positiva, la práctica judicial y la actuación de los poderes públicos». Si bien establece a renglón seguido la salvedad de que tales principios «Sólo podrán ser alegados ante la jurisdicción ordinaria de acuerdo con lo que dispongan las leyes que los desarrollen». Esta expresión, no muy afortunada, en modo alguno puede interpretarse como una prohibición para invocar o aplicar tales principios por los tribunales ordinarios, interpretación incompatible con el párrafo anterior de dicho precepto. En efecto continúa A.E. PÉrEZ LuÑo-, difícilmente se podría cumplir el imperativo constitucional de que las normas contenidas en dicho Capítulo III infor-

\footnotetext{
${ }^{25}$ R. Frondizi, ¿Qué son los valores?, Fondo de Cultura Económica, México-Buenos Aires, 1958; J. Ortega y Gasset, Obras Completas, Alianza Editorial, Madrid, 1983; A. Truyol Serra, Los derechos humanos, Ed. Tecnos, Madrid, 1984; A. Pérez Luño, J.L. CAscajo, B. Castro y C. Gómez TORRES, Los derechos humanos: significación, estatuto jurídico y sistema, Madrid, 1979.
} 
men la práctica judicial, si no pueden ser objeto de alegación ante o de aplicación por los tribunales ordinarios. De otro lado, en favor de la eficacia inmediata de estos derechos, conviene recordar que el artículo 96.1 de la Constitución proclama que los tratados internacionales, una vez publicados íntegramente en España, formarán parte del ordenamiento interno. Dado que España ratificó en 1977 el Pacto Internacional de los Derechos Económicos, Sociales y Culturales adoptado por la ONU en 1966, que incluye el reconocimiento de la mayor parte de los derechos consagrados en el Capítulo III del Título I de la Constitución, sería un grave error el desconocer el status normativo de estos derechos ${ }^{26}$.

Algún sector doctrinal ha recogido qué se entiende por derechos fundamentales ex constitutione y su titularidad. Así, de las diversas interpretaciones posibles derivadas de la Constitución que utiliza el término «derechos fundamentales» para dar rúbrica tanto a su Título I como a la Sección 1. ${ }^{a}$ del Capítulo II de dicho Título, se opta por la restricción del concepto de derechos fundamentales a aquéllos que están recogidos en los artículos 15 a 29 C.E., susceptibles de recurso de amparo constitucional y cuyo desarrollo normativo ha de realizarse por ley orgánica (SSTC 76/1983, de 5 de agosto, 26/1987, de 27 de febrero, con voto particular contrario, que considera también incluibles entre los derechos fundamentales a los recogidos en la Sección 2. ${ }^{a}$ de dicho capítulo II del Título I C.E., en cuanto sustraídos también a la disponibilidad del legislador en su contenido esencial en su artículo 53.1 C.E., 160/1987, de 27 de octubre). De los demás derechos protegidos en amparo, se considera también el derecho a la igualdad del artículo 14 C.E. (entre muchas otras SSTC 26/1987, 67/1988, 73/1988, $177 / 1988$ y 62/1990), mientras que en cambio se considera que no lo es el derecho a la objeción de conciencia que es definido como un derecho constitucional autónomo protegido por el recurso de amparo, pero cuya relación con la libertad ideológica del artículo 16 C.E. no permite ni autoriza para calificarle como derecho fundamental (SSTC 160/1987, de 27 de octubre y 61/1987, de 27 de octubre). Ahora bien, también debe tenerse presente que no todo lo regulado en los artículos 14 a 29 de la Constitución constituyen derechos fundamentales (SSTC 26/1987, de 20 de febrero y 62/1990, de 30 de marzo). Así, en particular:

— El artículo 16.3 C.E. regula un deber de cooperación del Estado con la Iglesia Católica y demás confesiones religiosas y no un derecho fundamental de los ciudadanos (STC 93/1983, de 8 de noviembre).

${ }^{26}$ A.E. Pérez LuÑo, Los derechos fundamentales, Ed. Tecnos, Madrid, 1988. 
- Ciertos apartados del artículo 27 C.E. —como el núm. 8- tampoco responden al concepto de derecho fundamental (STC 26/1987, de 27 de febrero) puesto que dicho artículo recoge preceptos de distinta naturaleza jurídica (STC 86/1985, de 10 de julio).

- El artículo 17.4 C.E., primera parte, esto es, lo relativo al procedimiento de habeas corpus (que ya había sido configurado como un medio de defensa de los derechos reconocidos en el resto del apartado del artículo 17 en STC 31/1985, de 5 de marzo), no contiene propiamente un derecho fundamental, sino una garantía institucional ${ }^{27}$ que resulta de la tutela judicial efectiva en todas sus vertientes (STC 44/1991, de 25 de febrero).

- Sin embargo, junto a ello es también cierto que allí donde, dentro de la Sección 1. a del Capítulo II del Título I C.E., se reconozca un derecho: su configuración como fundamental es precisamente el presupuesto de su ubicación (STC 26/1987, de 27 de febrero).

Como ha apuntado recientemente A. Gallego Anabitarte ${ }^{28}$, los derechos fundamentales tienen un doble carácter objetivo-subjetivo (STC 25/1981, de 14 de julio) y la relación que existe entre derechos fundamentales y garantía institucional ${ }^{29}$. La doctrina de la garantía institucional es acogida tempranamente, señalándose que el orden jurídico-político establecido por la C.E. asegura la existencia de determinadas instituciones a las que considera como componentes esenciales y cuya preservación se juzga indispensable para asegurar los principios constitucionales, estableciendo en ella un núcleo o reducto indisponible para el legislador. Las instituciones garantizadas son elementos arquitecturales indispensables del orden constitucional y las normativas que los protegen son normaciones organizativas, pero a diferencia con lo que sucede con las instituciones supremas del Estado, cuya regulación orgánica se hace en el propio texto constitucional, en éstas la configuración institucional concreta se remite al legislador ordinario, al que no se fija más límite que el reducto indispensable o indisponible o núcleo esencial de la institución que la Constitución garantiza. Esta garantía institucional que la Constitución garantiza no ase-

\footnotetext{
27 A. Gallego Anabitarte, Derechos fundamentales y garantías institucionales: análisis doctrinal y jurisprudencial (derecho a la educación, autonomía local y opinión pública), Ed. Civitas, Madrid, 1994.

28 A. Gallego Anabitarte, op. cit.

29 Téngase en cuenta que la tesis de la garantía institucional para ciertos institutos jurídicos elaborada en Alemania no tiene porqué servir de baluarte o defensa de los derechos fundamentales como correctamente se ha hecho según el profesor A. GALlego AnABitarte, por lo que debe ser tenido esto en cuenta pese a lo que se dice seguidamente en el texto.
} 
gura un contenido concreto o un ámbito competencial determinado y fijado de una vez por todas, sino la preservación de una institución en términos recognoscibles para la imagen que de la misma tiene la conciencia social en cada tiempo y lugar (STC 32/1981, de 18 de julio).

Ya se ha dicho que algún sector doctrinal ha estudiado con detenimiento la cuestión de los derechos fundamentales así como su doble aspecto subjetivo-objetivo y la garantía institucional para los casos en que procedan. Y del aspecto objetivo, el Estado estaría obligado a ${ }^{30}$ : a) respetar el ámbito de libertad que garantiza a los particulares los derechos fundamentales, b) modificar todo el ordenamiento jurídico, la organización y el procedimiento de acuerdo con los derechos fundamentales, dado su efecto irradiación, c) regular tanto los derechos fundamentales - cuando es necesario, por ejemplo, Ley de reunión, Ley de prensa, Ley de objeción de conciencia, etc. - o cualquier otro sector de manera que el derecho fundamental puede ser ejercido de manera real y efectiva, superando pues una actitud puramente de gendarme no intervencionista frente a los derechos fundamentales. Estamos aquí ante verdaderos encargos constitucionales al Estado, y, d) a otorgar subvenciones o cualquier otro tipo de prestaciones o servicios sin los cuales los derechos fundamentales no se pueden ejercer con plenitud ${ }^{31}$.

Me interesa ahora solamente dejar claro que la doctrina de la garantía institucional de origen alemán tiene un significado preciso — quizás también para la preservación de la colegiación en las profesiones tituladas y su ejercicio, con independencia de que estamos o no ante un derecho fundamental, que creo que no es el caso-, amparando ese minimum indisponible que el legislador ordinario debe respetar y que, precisamente por esa razón - también por otras, los Colegios profesionales han recibido el espaldarazo constitucional que se les había negado por entender su existencia contraria al principio de libertad de acción en la economía- su existencia ha sido declarada conforme a la Constitución y la garantía institucional alcanza a esta institución, que es en realidad una expresión de las facultades de policía y ordenación de la economía que el Estado tiene encomendadas y a la regulación de su existencia misma a la que tampoco el Estado puede renunciar, actuando tales instituciones, en cuanto tales, como aglutinadoras de intereses particulares y, en alguna medida, de intereses políticos ejercidos por aquellas (los Colegios Profesionales) por delegación del Estado. En esta última faceta de la actuación de estas actua-

\footnotetext{
${ }^{30}$ A. Gallego Anabitarte, op. cit.

31 A. Gallego Anabitarte, op. cit.
} 
ciones, evidentemente, es donde tiene plena aplicación el Derecho administrativo que es su Derecho regulador ${ }^{32}$.

La persistencia, pues, de los Colegios Profesionales y el ejercicio de las profesiones tituladas requiere de la intervención del Estado en el marco normativo y en el de vigilancia y control del funcionamiento de tales instituciones dentro de los límites constitucionales que, por lo demás, son comunes a todas las instituciones y que se contienen con el Título I de la Constitución. Antes de seguir con la exposición de las garantías institucionales que protegen la existencia de estas instituciones y que las hace acreedoras de un minimum existencial frente a la intromisión del legislador ordinario, conviene saber que, sobre los mismos, han existido, entre otros, los siguientes pronunciamientos del Tribunal Constitucional:

- En punto a la reserva de ley, sobre el régimen jurídico de las profesiones tituladas y de los Colegios Profesionales, «la garantía de las libertades y derechos consiste en que esta materia sea regulada por el legislador, que no encuentra, como es obvio, otros límites, por los derivados del resto de los preceptos de la Constitución».

- El legislador, atendiendo a las exigencias del interés público y a los datos producidos por la vida social, decide considerar cuándo una profesión debe dejar de ser enteramente libre para pasar a ser titulada.

- El mandato de democracia en la estructura y funcionamiento de los Colegios es en su modo de organización y de actuación y no en las consecuencias producidas por su creación.

- La función de ordenar la profesión que contempla con carácter general el artículo 3 de la Ley de Colegios, de acuerdo con este artículo 36 C.E., sólo puede ejercerse dentro de los límites marcados por las atribuciones ordenadas por la ley, las cuales a su vez deben ser objeto de una interpretación estricta. La razón estriba en que las regulaciones que limitan la actividad de quienes desarrollan actividades profesionales y empresariales no dependen del arbitrio de las autoridades o corporaciones administrativas. Por un lado, el principio constitucional general de libertad (arts. 1.1 y 10.1) autoriza a los ciudadanos a llevar a cabo todas aquellas actividades que la Ley no prohíba, y cuyo requisito no subordine a requi-

\footnotetext{
${ }^{32}$ Ley 2/1974, de 13 de febrero (modificada en 1978) y posteriormente por Ley 7/1997, de 7 de abril, de medidas liberalizadoras en materia de suelo y Colegios Profesionales. Abundaremos sobre todo ello.
} 
sitos o condiciones determinadas. Por otro lado, el principio de legalidad que consagran los artículos 9.3 y 103.1 y que alcanza alcanza de lleno a los Colegios Profesionales cuando ordenan el ejercicio de las profesionales tituladas (art. 36 C.E.) impide a las Administraciones públicas dictar normas sin una habilitación legal suficiente (STC 93/1992, de 11 de junio). La necesaria adecuación entre el principio democrático del artículo 36 y una regla estatutaria por los que se prohíbe que de las Juntas de Gobierno de los Colegios formen parte aquellos colegiados que las propias Juntas consideren que representan intereses contrapuestos a los de la organización colegial en todo caso obliga a considerar que el principio democrático, dada su prevalencia frente a la regla estatutaria, impone una interpretación restrictiva de éste, lo que, en concreto, significa que se entienda que no estamos ante una causa de inelegibilidad sino de incomptabilidad (STS 166/1992, de 26 de octubre) ${ }^{33}$. Tampoco parece conveniente olvidar que, por su parte, la STC 131/1989, de 19 de julio, se pronuncia sobre la colegiación obligatoria de médicos que ejercen en el Instituto Nacional de la Salud y no con independencia, entendiéndola correcta por estarse en todo caso en el ejercicio de la profesión médica. También hay que resaltar que la STC 219/1989, de 21 de diciembre, versa acerca de la naturaleza y fuerza de las normas colegiales, permitiendo que se sancione a un colegiado por su infracción por estarse en una relación de sujeción especial ${ }^{34}$. Yo discrepo abiertamente de esto último en cuanto pretende utilizar el instituto para justificar teóricamente la imposición de sanciones a arquitectos, médicos o abogados. Además, abona mi tesis el hecho evidente de que la sanción disciplinaria no puede ser impuesta sino por el órgano que ostenta la competencia. Estas tesis están más próximas al Derecho prusiano que a la realidad sociológica española y del instituto de las relaciones especiales de sujeción.

En cuanto a la garantía institucional, que puede amparar la configuración mínima de los Colegios profesionales cuya existencia está constitucionalmente garantizada, señala el profesor A. Gallego Anabitarte que los análisis de Stern y Maunz-Durig-Herzog-Scholz pretenden mantener el valor de este concepto, como algo diferente al resto de las técnicas que explican el contenido objetivo de los derechos fundamentales (en síntesis, los derechos fundamentales como valores (principios) objetivos del todo el ordenamiento jurídico al que irradian su eficacia; y los derechos funda-

\footnotetext{
${ }^{33}$ STC 42/1986, de 10 de abril.

${ }^{34}$ F.J. JimÉNeZ LeChUGA, «Relaciones de especial sujeción y límites constitucionales: especial referencia al caso de los militares, los funcionarios y los enfermos hospitalarios», RArAP núm. $17 / 2000$.
} 
mentales como normas jurídicas objetivas que exigen una acción positiva del Estado). Para estos autores la garantía institucional o garantía de instituto es algo más preciso que lo que se conoce como un enfoque institucional-axiológico-sociológico, ya que ella significa para estos autores la protección jurídico constitucional de supuestos de hechos normativos cerrados o complejos normativos determinados, que constituyen un determinado objeto que se garantiza como institución (organización) jurídicoconstitucionalmente ${ }^{35}$. Como se ha referido anteriormente al hablar de la garantía institucional, o más claramente la institución garantizada constitucionalmente tenemos que estar ante una situación de hecho y normativa, formada, heredada, con raíces históricas y por todo ello «encontrada» como ocurre por ejemplo con la familia y el concepto burgués de propiedad, pero no con la libertad de expresión, opinión pública, prensa, etc. ${ }^{36}$. Las garantías institucionales pueden ser jurídico privadas (propiedad, herencia, matrimonio, etc.) y jurídico públicas (autonomía local, función pública, etc.); éste es el dualismo entre garantías de institutos jurídicos y garantías institucionales (en sentido estricto). Además, las garantías institucionales (en sentido amplio) pueden estar referidas a derechos fundamentales (por ejemplo, garantía escolar artículo 7 de la Ley Fundamental, libertad de ciencia-autonomía universitaria (art. 5.3), nacionalidad (art. 16 Ley Fundamental), grandes comunidades religiosas (art. 140 Ley Fundamental) o pueden no tener relación con los derechos fundamentales (autonomía local, art. 28.2, independencia de los jueces (art. 97), partidos políticos (art. 21). Para este sector doctrinal, este sentido estricto de garantía institucional conduce a descartar que se encuentren en determinados derechos fundamentales (por ejemplo, la libertad artística, etc.), garantías institucionales, opinión que indudablemente mantenemos ${ }^{37}$.

\section{EL ESTATUTO JURÍDICO DE LA ABOGACÍA ESPAÑOLA}

Parece ahora oportuno detenerse un momento en el estudio de algunos rasgos que configuran el ejercicio de la profesión de abogado que es lo que ahora nos interesa y que tiene su origen - al menos su respaldo constitucional- en el artículo 36 de la Constitución y en la Ley de Colegios Profesionales de 1974 modificada posteriormente en 1978 y 1997, respectivamente. Pero, con independencia de la regulación que del ejercicio de la

\footnotetext{
35 Maunz-Durig-Herzog et alli, Grundgesetz. Kommentar, 1991.

${ }^{36}$ Maunz-Durig-Herzog et alli, op. cit.

${ }^{37}$ Vid. mi comentario al libro citado en las notas núms. 27, 28, 29, 30 y 31 en núm. 136/1995 de la $R A P$.
} 
profesión de abogado realiza cada uno de los Colegios de España en sus Estatutos, conviene detenerse en el análisis del Estatuto General de la Abogacía Española, aprobado por Real Decreto 2090/1982, de 24 de julio ${ }^{38}$. Y los Colegios profesionales de Abogados son Corporaciones de Derecho público amparados por la Ley y reconocidas por el Estado, con personalidad jurídica propia y plena capacidad para el cumplimiento de sus fines. Son fines esenciales de estas Corporaciones la ordenación del ejercicio de la profesión, la representación exclusiva de la misma, la defensa de los intereses profesionales de los colegiados, el cumplimiento de la función social que a la Abogacía corresponde y, la colaboración en la promoción y administración de la Justicia (art. 3 EAE). Son funciones de los Colegios de Abogados las siguientes: a) Colaborar con el Poder Judicial y con la Administración mediante la realización de estudios, emisiones de informes, elaboración de estadísticas y otras actividades relacionadas con sus fines, que le sean solicitadas o acuerden por propia iniciativa, b) Ostentar la representación que establezcan las leyes para el cumplimiento de sus fines, c) Participar, en materias de la profesión, en los Consejos u órganos consultivos de la Administración, d) Tomar parte en los Patronatos Universitarios, e) Participar en la elaboración de los planes de estudios, informar las normas de organización de los centros docentes a la profesión, mantener permanente contacto con los mismos, proponer la creación de Escuelas de Práctica Jurídica y otros medios para facilitar el acceso a la vida profesional de los nuevos titulados, y organizar cursos para la formación y perfeccionamiento profesional, f) Ostentar, en su ámbito, la representación y defensa de la profesión ante la Administración, Instituciones, Tribunales, Entidades y particulares, con legitimación para ser parte en cuantos litigios y causas afecten a los intereses profesionales y fines de la Abogacía y ejercitar el derecho a la petición conforme a la ley, g) Ordenar, en el ámbito de su competencia, la actividad profesional de los colegiados, velando por la ética y la dignidad profesional y por el respeto debido a los derechos de los particulares y ejercer la facultad disciplinaria en el orden profesional y colegial $^{39}$, h) Organizar y promover actividades y servicios comunes de interés para los colegiados, de carácter profesional, formativo, cultural, asistencial y de previsión y otros análogos ${ }^{40}$, i) Procurar la armonía y colaboración entre los colegiados impidiendo la competencia desleal entre los mismos, j) Adoptar las medidas conducentes a evitar y perseguir el intrusismo profesional, k) Intervenir, previa solicitud en vía de conciliación y

\footnotetext{
${ }^{38}$ BOE de 2 de septiembre y correcciones del día 8 de octubre.

${ }^{39}$ Facultades que entiendo no encajan en las llamadas relaciones especiales de sujeción.

${ }^{40}$ La Mutualidad General de la Abogacía Española es el órgano sobre quien recae la previsión social de los Abogados.
} 
arbitraje en las cuestiones que, por motivos profesionales, se susciten entre los colegiados, 1) Resolver las discrepancias que puedan surgir en relación con la actuación profesional de los colegiados y la percepción de sus honorarios, mediante laudo al que, previamente, se sometan las partes interesadas, ll) Regular los honorarios mínimos u orientadores de los colegiados, m) Informar y dictaminar sobre honorarios profesionales en los procedimientos judiciales o administrativos, n) Cumplir y hacer cumplir a los colegiados las leyes en cuanto afecten a la profesión; y los Estatutos, normas y disposiciones adoptadas por los órganos colegiados en materias de su competencia, $\tilde{n})$ Cuantas otras funciones redunden en beneficio de los intereses de la profesión y de los colegiados, y demás fines de la Abogacía, y, o) Las demás que vengan dispuestas por la legislación ${ }^{41}$.

Los artículos 39 a 60 del Estatuto General de la Abogacía Española recogen los derechos y deberes de los colegiados. En particular, el Abogado tiene el derecho y el deber de guardar secreto profesional. El secreto profesional constituye al Abogado en la obligación y en el derecho de no revelar ningún hecho ni dar a conocer ningún documento que afecten a su cliente, de los que hubiera tenido noticia por él mismo en razón del ejercicio profesional. En el caso de que el Decano de un Colegio o quien reglamentariamente le sustituya, fuera avisado por la autoridad judicial, o en su caso gubernativa, competente de la práctica de un registro en el despacho profesional de un Abogado, deberá personarse en dicho despacho y asistir a las diligencias que en el mismo se practiquen velando por la salvaguarda del secreto profesional (art. $41 \mathrm{EAE}$ ). El Abogado, en cumplimiento de su misión, actuará con toda libertad e independencia, sin otras limitaciones que las impuestas por la ley y por las normas de la moral y deontológicas (art. $42 \mathrm{EAE})^{42}$.

\footnotetext{
${ }^{41}$ El Estatuto General de los Procuradores de los Tribunales de España aprobado por Real Decreto de 30 de julio de 1982 .

42 En igual sentido el artículo 24 de los Estatutos del Ilustre Colegio de Abogados de Granada aprobados el 17 de junio de 1983 y el artículo 23 y sigs. del Estatuto del Consejo Andaluz del Colegio de Abogados aprobados por Orden de 11 de diciembre de 1996. «... No obstante, téngase en cuenta lo que establece el Real Decreto 658/2001, de 22 de junio, por el que se aprueba el Estatuto General de la Abogacía Española (derogando, por tanto, el anterior), los Estatutos del Ilustre Colegio de Abogados de Granada, aprobados por la Junta General Extraordinaria de ese Ilustre Colegio, de 24 de enero de 2001, y sancionados por el Pleno del Consejo General de la Abogacía Española en sesión de 22 de junio siguiente (entrando en vigor el 1 de septiembre de 2001), la Ley 6/1995, de 29 de diciembre, de Consejos Andaluces de Colegios Profesionales, la Orden de 11 de diciembre de 1996, por la que se declara la adecuación a la legalidad de los Estatutos del Consejo Andaluz de Colegios de Abogados, el Código Deontológico de la Abogacía Española, en su redacción dada por acuerdo de 29 de junio de 1995, el Decreto 5/1997, de 14 de enero, por el que se aprueba el Reglamento de Consejos Andaluces de Colegios Profesionales y, finalmente — sin
} 
Hay que tener en cuenta que el deber de defensa jurídica que a los Abogados se confía es también un derecho para los mismos, pudiendo reclamar tanto a las Autoridades como a los particulares, todas las medidas en ayuda de su función que le sean legalmente debidas. También el Abogado tiene derecho a todas las consideraciones honoríficas debidas a su profesión y tradicionalmente reconocidas (arts. 43 y 44 EAE). Para la protección de sus derechos, los Abogados podrán hacer uso de cuantos remedios o recursos establece la vigente legislación, sujetándose al régimen jurídico presente para cada uno de ellos. Si el Letrado entendiere que no se le guarda el respeto debido por el Fiscal, compañero contradictor u otra persona, podrá intervenir haciéndoselo presente al Juez o Tribunal para que por éste se ponga el remedio adecuado (art. $45 \mathrm{EAE}$ ).

De la responsabilidad penal, civil y disciplinaria de los Abogados se ocupan los artículos 100 a 122 del Estatuto General de la Abogacía Española a los que ahora remito.

Es evidente, por lo demás, que la policía de estrados, facultad correccional de la que gozan los jueces y tribunales, está también regulada en la Ley Orgánica 6/1985, de 1 de julio, del Poder Judicial y en las Leyes de Enjuiciamiento Civil y Criminal, respectivamente ${ }^{43}$. Resulta trascendental, desde luego, a los efectos que ahora importan, la escueta regulación que sobre los Abogados ejercientes contiene esta trascendental pieza legal del ordenamiento jurídico español. Según su propia dicción, corresponde en exclusiva la denominación y función de abogado al licenciado en Derecho que ejerza profesionalmente la dirección y defensa de las partes en toda clase de procesos, o el asesoramiento y consejo jurídico (art. 146 LOPJ). En su actuación ante los Juzgados y Tribunales, los Abogados son libres e independientes, se sujetarán al principio de buena fe, gozarán de los derechos inherentes a la dignidad de su función y serán amparados por aquéllos en su libertad de expresión y defensa. Los Abogados deberán guardar secreto de todos los hechos o noticias de que conozcan por razón de cualquiera de las modalidades de su actuación profesional, no pudiendo ser obligados a declarar sobre los mismos (art. 437 LOPJ) ${ }^{44}$.

\footnotetext{
ánimo de ser exhaustivo-, el Estatuto de Abogados Jóvenes del Ilustre Colegio de Abogados de Granada, aprobado por la Junta General, el 26 de noviembre de 1976 y modificados por acuerdo de la Junta General Extraordinaria de 24 de febrero de 1984».

${ }^{43}$ Téngase presentes en este terreno las novedades introducidas por la Ley 1/2000, de 7 de enero, de Enjuiciamiento Civil.

${ }^{44}$ Éste es un precepto de singular importancia a los efectos de este estudio.
} 
No conviene olvidar tampoco que, en relación con lo que ahora se dirá, el artículo 24.2 de la Constitución establece que todos tienen derecho «a la defensa y a la asistencia de Letrado». Como recuerda la STC 42/1992, se trata de un derecho que no ha sido incorporado a nuestro ordenamiento por la Constitución, pues nuestro Derecho lo conocía ya de antaño y en su regulación original y la institución misma del proceso, cuya importancia decisiva para la existencia del Estado de Derecho es innecesario subrayar. Las normas existentes sobre asistencia letrada, sigue afirmando esta sentencia, han de ser reinterpretadas y contempladas de conformidad con la Constitución y en ningún caso cabe transformar un derecho fundamental que es simultáneamente un elemento decisivo del Derecho penal en un mero requisito formal. Resulta claro que nuestro ordenamiento garantiza constitucionalmente el derecho a la defensa técnica de la parte a través de un profesional de la abogacía. Pese a que el artículo 6.3, c) del Convenio Europeo para la Protección de los Derechos Humanos, por su parte, reconoce el derecho del acusado a la asistencia gratuita por un Abogado de oficio, si no tiene medios para pagarlo y cuando los intereses de la justicia lo exijan. En línea con este precepto el Tribunal ha venido entendiendo que corresponde también al acusado el derecho a que se le designe defensa letrada de oficio también en los casos en los que aunque la defensa letrada no sea preceptiva se ha solicitado nombramiento de Letrado de oficio por carecer de medios económicos. Así, según la STC 47/1987, el derecho a la defensa y la asistencia letrada impone a los órganos judiciales el deber positivo de evitar desequilibrios entre las diversas posiciones procesales de las partes o limitaciones en la defensa susceptibles de ocasionar indefensión, que se puede producir cuando se priva a quien adolece de insuficiencia de recursos para litigar de la posibilidad efectiva de ser asistido por letrado, denegándole el derecho a que se le nombre de oficio, el derecho reconocido en el artículo 24.2 de la Constitución no sólo incluye el derecho de la parte en el proceso a poder designar un Letrado de su elección, sino también a que, cuando corresponda, le sea designado un Letrado de oficio $^{45}$.

Hay que tener en cuenta que las reglas procesales y el derecho a la libertad de expresión no deben estar reñidos ya que la defensa de los Abogados en el ejercicio de su actuación forense - art. 437.1 LOPJ— se vincula y tiene su raíz en el artículo 20.1, a) C.E. (STC 38/1988, de 9 de marzo), hay que resaltar que las expresiones proferidas durante un proceso están sometidas a los requisitos de éstos, por lo que no se vulnera el artículo 20 por las mismas (STC 30/1986, de 20 de febrero).

${ }^{45}$ STC 38/1988, de 9 de marzo. 
Se ve claramente, pues, que el Abogado tiene reconocido en principio, como cualquier otro ciudadano, su derecho a la libre expresión en el ejercicio de sus funciones. Ahora bien, este derecho fundamental será reclamable cuando se ejercite la «autodefensa» con los límites legales existentes. Cuando ejercita la defensa de clientes cabe hablar de dos derechos fundamentales en juego, los de los artículos 24.1 y 2 y el 20.1, a) de la Constitución. Parece, por consiguiente, que en la colisión entre los tres derechos fundamentales referidos (en realidad estamos ante un haz de derechos fundamentales más amplios que se desprenden de estos tres preceptos constitucionales), debe prevalecer el derecho a la libertad de expresión, pero con sus límites en el derecho a la intimidad, personal, honor y propia imagen y, más particularmente, el principio de la ponderación de los intereses en juego. Se ha afirmado por ello que todo esto comporta o se concreta en un proceso de ponderación de los bienes o derechos protegidos en conflicto, utilizando todos estos puntos de vista o tópicos que se han indicado. En los últimos años, el Tribunal Constitucional parece haberse inclinado decididamente por este enfoque de ponderar los derechos en conflicto, frente al primer enfoque «institucional» que son su énfasis sobre la garantía de la opinión pública no llevaba a una ponderación sino a un enfoque unidimensional y no equilibrado ${ }^{46}$.

Es objetivo de este trabajo deslindar claramente el contenido del derecho fundamental a la libertad de expresión y su ejercicio en relación con las profesiones liberales. Más particularmente, interesa destacar la doble faceta que supone el ejercicio de defensa de los abogados cuando intervienen en nombre propio y este derecho fundamental, así como cuando lo hacen en funciones de asistencia técnica y defensa de sus clientes y, por consiguiente, la influencia positiva que en este último caso tiene el artículo 20.1, a), en el segundo caso, y, de manera singular, el 24.1 y 2 C.E., en el primer caso. Esto lo expondré con más detenimiento en los dos siguientes apartados de esta modesta contribución a un asunto cuya importancia y repercusión social nadie puede negar en nuestro tiempo.

\section{LA DOCTRINA DEL TRIBUNAL CONSTITUCIONAL EN EL CASO CONCRETO AL QUE SE ALUDE CON OCASIÓN DE LA PROBLEMÁTICA DEL BINOMIO LEGALIDAD-SUPRALEGALIDAD}

Entramos ahora en la exposición de este curioso caso en el que un Abogado holandés es perseguido penalmente por el contenido de un escrito

${ }^{46}$ A. Gallego Anabitarte, op. cit. 
que dirige al entonces Fiscal Jefe del Tribunal Superior de Justicia de Andalucía ${ }^{47}$, instándole, al parecer, en base al artículo 124 C.E. y a sus facultades como Letrado, a que instase el impulso de las averiguaciones necesarias en un caso del que se encontraba encargado el Sr. Johannes van Hoff a la sazón. Fue condenado como un reo o responsable de una falta a una simple multa que confirmó más tarde la Audiencia Provincial de Granada y que, posteriormente, la STC 113/2000, de 5 de mayo, declara nula — junto con la del Juzgado de Instrucción núm. 2 de Baza (Granada) — al entenderlas contrarias al derecho fundamental a la libertad de expresión del Abogado Sr. van Hoff. Sin entrar ahora en el análisis del proceso que motivo el escrito del Abogado holandés al Sr. Fiscal Jefe, es lo cierto que, según la citada sentencia del Tribunal Constitucional (aparts. a) y b) STC 113/2000, de 5 de mayo), por decreto del Fiscal Jefe del Tribunal Superior de Justicia de Andalucía, de 17 de abril de 1996, se acordó dar contestación al escrito del Sr. van Hoff, en el cual «se traslucen expresiones que ponen en entredicho las actuaciones de la Sra. Abogado Fiscal» y decretó el archivo del expediente. En esta misma fecha, el Fiscal Jefe dirigió escrito al Sr. van Hoff contestando a su petición, señalando que carecía de todo fundamento formular su petición a esa Jefatura para que diese instrucciones al Fiscal de la causa a fin de solicitar el sobreseimiento provisional de las diligencias penales, poniendo en duda además «la capacidad profesional y de decisión que a la misma (a la Sra. Fiscal)» compete. Añadía en su escrito el Fiscal Jefe que las peticiones dichas deberían cursarse a través de los instrumentos procesales dispuestos a tal fin en las leyes procesales, que en todo caso no eran los de dirigirse al superior jerárquico del Fiscal en cuestión para pedir que ordenase al mismo una actuación procesal favorable a los intereses de una parte, al margen de lo hecho por el Fiscal en esa ocasión sí había sido procedente y ajustado a Derecho. Finalizaba su escrito señalando que «las expresiones e imputaciones que de su conducta procesal se contienen en el escrito del recurso del Sr. Letrado transpasan, a nuestro entender, lo que debe ser el cabal y correcto ejercicio de la profesión y la legitima defensa de los intereses de la parte, al insinuar, cuando menos, un propósito, a todas luces inexistente, de vulnerar garantías constitucionales por parte de la representante del Ministerio Fiscal» ${ }^{48}$. Por oficio del Tribunal Superior de Justicia de Andalucía de 17 de abril de 1966, y suscrito por el Fiscal Jefe, se remitió al Juzgado de Instrucción núm. 1 de Baza, copias de las actuaciones seguidas a resultas de la comparecencia del Sr. van Hoff y de las «expresiones contenidas en el escrito

\footnotetext{
${ }^{47}$ D. Luis Portero García, asesinado por ETA el día 9 de octubre de 2000 en Granada.

48 J. Aguilere GonZÁlez, «Libertad de defensa y libertad de expresión», Boletín Informativo del Ilustre Colegio de Abogados de Granada («Plaza Nueva») núm. 31/2000, p. 41.
} 
de recurso» que pudieran ser constitutivas de una falta del artículo 570.1 C.P. de 1973 (art. 634 C.P. de 1995), que afectaban tanto al Ministerio Fiscal como a la Autoridad Judicial, a fin de que se depurasen las oportunas responsabilidades. Al oficio citada acompaña escrito de 12 de abril de 1996, se presume que del fiscal actuante en el procedimiento abreviado en cuestión y dirigido al Fiscal Jefe del Tribunal Superior de Justicia de Andalucía, en el que se informaba sobre las diligencias practicadas y 1 as razones que llevaron al Fiscal a la petición de nuevas diligencias, tras dictarse el Auto de incoación del procedimiento abreviado.

Mediante Auto de 25 de abril de 1996 - sigue exponiendo el T.C. en la sentencia comentada-, el Juzgado de Instrucción núm. 1 de Basa acordó incoar diligencias previas, ordenando se recibiese declaración al ahora recurrente en amparo, Sr. van Hoff, con lectura del artículo 118 de la LECrim. Por nuevo Auto de 21 de junio de 1996, se calificaron los hechos constitutivos de una eventual falta, convocándose a las partes a la celebración del pertinente juicio verbal. El 26 de julio de 1996 se dictó sentencia por el Juez de Instrucción condenando al Sr. van Hoff como autor criminalmente responsable de una falta del artículo 570.1 C.P. de 1973 a la pena de 5.000 ptas. de multa y costas. En dicha sentencia se razonaba, tras una breve referencia sobre la función garante de la libertad de expresión y el derecho de defensa de los «poderes públicos» y sobre la libertad e independencia de la actuación de los Letrados en su ejercicio profesional ante los órganos judiciales, que la circunstancia que hizo punible su conducta no había sido tanto lo dicho en el escrito de interposición del recurso de reforma, que de suyo sería insuficiente para tener por típica la conducta, como el hecho de que, además, hubiese dirigido un escrito al Fiscal Jefe del Tribunal Superior de Justicia de Andalucía al margen de las vías procesales pertinentes, sin fundamento alguno, y con el claro objetivo de «poner en duda la capacidad profesional de decisión» del Fiscal actuante en la causa penal (fundamento de derecho 2. ${ }^{\circ}$ ). Por sentencia de 6 de noviembre de 1996, la Sección Primera de la Audiencia Provincial de Granada desestimó la interpelación, mejor apelación interpuesta por el ahora recurrente en amparo, Sr. van Hoff, contra la del Juzgado de Instrucción. Argumentaba la Audiencia Provincial que si bien es cierto que la LOPJ y la doctrina jurisprudencial han reconocido la libertad de expresión al Abogado en el ejercicio de su actividad profesional, no lo es menos que esa libertad encuentra su límite en otros bienes e intereses dignos de protección, debiéndose ponderar entre una y otros en caso de colisión.

Señala el recurrente —entre otros extremos que omito por no hacer extensiva aquí la cita de los antecedentes de hecho el caso controvertido- 
que, mientras el principio de autoridad constituye un principio general del Derecho, y también del Derecho constitucional, que sirve a otros fines y a la garantía de otros bienes anudados al ejercicio de sus funciones por los poderes públicos, la libertad de expresión se sitúa por la Constitución en un plano superior, habida cuenta de que es un bien social en sí misma, que no requiere de que su ejercicio esté en función de la formación de la opinión pública, para prevalecer sobre otros, mereciendo la máxima protección constitucional. Así, la libertad de expresión encarna un interés superior y público de valor superior al principio de autoridad, que aunque también encarna un interés público, su función subordinada a la garantía de otros bienes, supone, y así lo ha querido la Constitución, que su salvaguarda ceda en todo caso ante el imperativo del ejercicio de la libre expresión de las ideas, opiniones y pensamientos. Con ello no se trata de decir, advierte el demandante de amparo, que es inútil la sanción penal de las conductas que menoscaben la autoridad de los poderes públicos, sino que el «principio de autoridad» no puede constituir en ningún caso un límite externo a la libertad de expresión, lo que nunca es posible ${ }^{49}$, sino que las expresiones típicas no, son objeto de la protección constitucional que dispone el artículo 20.1, a) C.E. al quedar fuera de su ámbito de garantía. A tal fin el recurrente procede a ponderar los derechos e intereses en presencia ${ }^{50}$, alegando que, con arreglo a lo dispuesto en el artículo 437.1 LOPJ, el ejercicio de su profesión como Abogado es libre e independiente y amparado por la libertad de expresión y defensa. La conducta observada por él en el caso de autos fue una manifestación del libre e independiente ejercicio de su profesión en uso de su libertad de expresión y defensa, cuya finalidad era criticar la actuación procesal del Ministerio Fiscal, que en su condición de sujeto que ejerce poder público está sometido a la critica pública, que deberá soportar aun cuando le resulte hiriente o molesta. En el caso concreto, además, las expresiones críticas para con el Ministerio Fiscal no se dirigían contra la persona que lo representaba, sino contra su proceder, y estaban ayunas de descalificaciones personales, expresiones insultantes o innecesarias, o críticas atentadas por un ánimo vejatorio. Dichas controvertida s opiniones fueron expresadas en el transcurso de un proceso penal y por el cauce idóneo, alentadas por su interés en la defensa de su cliente. Así las cosas, entiende el recurrente que su condena en aplicación del artículo 570.1 C.P. de 1973 es el resultado de una interpretación extensiva in malem partem de la norma penal lesiva del artículo

\footnotetext{
49 F.J. JimÉnEZ LeChUGA, «Derecho Administrativo sancionador. Principios de legalidad y reserva de ley frente a la potestad reglamentaria de la Administración», RArAP núms. 6-7/1995.

${ }^{50}$ Ésta es ciertamente la posición del Tribunal Constitucional y así lo advirtió en su momento oportuno A. Gallego Anabitarte y yo mismo.
} 
25.1 de la Constitución, generando un pernicioso efecto disuasorio, pues pendería sobre el ciudadano la amenaza de que la critica dirigida contra un poder público, aunque esté expresada con corrección, puede ser perseguida penalmente. También solicitó el recurrente la suspensión de la Sentencia del Juzgado de Instrucción núm. 1 de Basa (Granada).

Ya en los Fundamentos jurídicos, y por lo que a nosotros ahora interesa, expone el Ministerio Fiscal que estima procedente otorgar el amparo solicitado. En primer lugar, porque los órganos judiciales han desconocido la doctrina del TC sobre la prevalencia de la vía disciplinaria establecida en los artículos 446 y sigs. LOPJ que han venido a despenalizar estas conductas si han de ser tenidas como constitutivas de falta, citando al efecto las SSTC 38/1988, de 30 de marzo y 92/1995, de 25 de junio. En segundo lugar, y pasando al examen de la cuestión de fondo, porque ha de atenderse al carácter reforzado de la libertad de expresión cuando se hace valer en el marco del ejercicio de defensa, con cita, al efecto, de las SSTC 205/1994, de 11 de julio y 157/1996, de 5 de octubre ${ }^{51}$. Indica el Ministerio Público que el demandante de amparo había actuado con el ánimo de servirse de los medios procesales a su alcance para obtener un pronunciamiento favorable a los intereses de su cliente, intentando, a tal fin, evitar una actuación del Ministerio Fiscal del caso que, a su juicio, lesionaba gravemente los derechos de su defendido a la libertad personal y a la tutela judicial efectiva. Señalaba, además, que, si lo realmente controvertido, era el tono del escrito dirigido al Fiscal Jefe del Tribunal Superior de Justicia de Andalucía, no puede soslayarse que, con arreglo al Estatuto Orgánico del Ministerio Fiscal, aquél puede impartir instrucciones respecto de la actuación de los miembros del Ministerio Público que le estén subordinados.

$\mathrm{Y}$, en lo que también aquí ahora interesa, añade la sentencia objeto ahora de nuestra atención que ${ }^{52}$ el examen de los hechos permite llegar a la conclusión de que ha de otorgarse el amparo, máxime si se atiende a la doctrina del TC sobre el carácter reforzado de la libertad de expresión cuando se hace efectiva en el marco del ejercicio del derecho de defensa. En tal sentido, se ha dicho en la STC 205/1994 (FJ 5. ${ }^{\circ}$ ) que «el reconocimiento constitucional del derecho a la tutela judicial que asiste a todos los ciudadanos (art. 24.1 C.E.) y el carácter esencial que para el funcionamiento de la Justicia revista la figura del Abogado, impone, y así se ha recogido en la legalidad ordinaria (art. 437.1 LOPJ) que en la actuación ante los Jueces y Tribunales los Abogados sean libres e independientes,

\footnotetext{
51 STC 157/1996, de 15 de octubre.

52 STC 113/2000, de 5 de mayo (BOE núm. 136, de 7 de junio, Suplemento).
} 
gozando, de los derechos inherentes a la dignidad de su función, por lo que deberán ser amparados por aquellos en su libertad de expresión del Abogado en el ejercicio de la libertad de defensa y de expresión. Sigue diciendo esta sentencia, en el expresado fundamento jurídico, que la libertad de expresión del Abogado en el ejercicio de la libertad de defensa es una manifestación cualificada del derecho reconocido en el artículo 20 C.E., porque se encuentran vinculada con carácter inescindible a los derechos de defensa de la parte (art. 24 C.E.) y a los órganos jurisdiccionales (para su adecuado funcionamiento) en el cumplimiento del propio y fundamental papel que la Constitución les atribuye (art. 117 C.E.), de modo que se trata de una manifestación de la libertad de expresión especialmente resistente, inmune a restricciones que es claro que en otro contexto habrán de operar. Sin embargo, sigue diciendo dicha sentencia, esta especial cualidad de la libertad de expresión se ha de valorar atendiendo a su funcionalidad para el logro de las finalidades que justifican su privilegiado régimen, sin que ampare el reconocimiento del mismo respeto debido a las demás partes presentes en el procedimiento y a la «autoridad e imparcialidad del Poder Judicial» que el artículo 10.2 C.E.D.H. erige en límite explícito de la libertad de expresión (STEDH de 22 de diciembre de 1989, caso Barford) ${ }^{53}$. Hay, una línea jurisprudencial reciente que tiende a primar la prevalencia del derecho a la libertad de expresión sobre el derecho al honor (SSTS de 21 de enero de 1988, Ar. 409, 12 de febrero de 1991, Ar. 1010, 12 de abril de 1991, Ar. 2621, 3 de junio de 1988, Ar. 4430, 26 de septiembre de 1989, Ar. 6819, 1, de febrero de 1991, Ar. 1027, 22 de abril de 1991, Ar. 2927, 25 de octubre de 1991, Ar. 7394 y 19 de noviembre de 1991, Ar. 8327) ${ }^{54}$.

Antes de finalizar el comentario a la STC 113/2000, de 5 de mayo, conviene traer aquí a colación otra decisión del propio TC de 11 de julio de 1994, que se refiere al derecho fundamental a la libertad de expresión y el derecho de defensa de los Abogados ${ }^{55}$, según la cual — siempre en lo que

\footnotetext{
${ }^{53}$ Artículo 5.2 Grundgesetz für die Bundesrepublik Deutschland vom 23. Mai 1949. Incomprensiblemente la referencia a la libertad de prensa y radiodifusión está ausente en el artículo 20 C.E. Hay, desde luego, referencias indirectas.

${ }^{54}$ STS de 21 de enero de 1988, Ar. 409. Dice así:

«... corresponde a los órganos judiciales (y aquí remite a la sentencia de 16 de diciembre de 1986) asumir la interpretación más favorable al derecho fundamental y a la producción de sus efectos (en orden a la libertad de expresión), incluso sobre las normas penales limitadoras de la misma. Todas las interpretaciones al mismo han de recibir una interpretación restrictiva. Así pues, la contradicción y colisión entre ambos derechos en pugna concede, en este caso, llevada a cabo la correspondiente ponderación (esto último debe figurar en cursiva), sobre criterios constitucionales, a la solución ya citada».
}

55 J. GonZÁlez Pérez, «Los obstáculos del acceso a la justicia administrativa», REDA núm. 83/1994. 
aquí importa- (Recurso de amparo 2379/1991) dice que 1a violación del derecho fundamental consagrado en el artículo 24.2 no tuvo lugar sin más, si siempre que el proceso tenga una duración anormal —en el supuesto de que éste sea el caso, lo cual es más que dudoso- y que, en cualquier caso, lo que no puede es aducirlo cuando el proceso ya ha finalizado sin que previamente se haya invocado ante el Juez o Tribunal ${ }^{56}$. Las correcciones impuestas (correcciones disciplinarias, claro está) por los Jueces y Tribunales a los Abogados en el uso de un procedimiento, haciendo uso de 1a llamada policía de estrados, así como las resoluciones revisoras de las mismas, no son actos materialmente administrativos, sino resoluciones judiciales dictadas en un proceso con todas las garantías, con lo que satisface el derecho del interesado a la tutela judicial. Por consiguiente, la resolución judicial por la que se declara la inadmisibilidad del recurso contencioso-administrativo, no atenta contra el derecho fundamental a obtener una resolución razonada con base en la legalidad ordinaria, ni como medio necesario para acceder a la revisión judicial ${ }^{57}$.

Ninguna violación del derecho de defensa se ha producido por la circunstancia de haberse impuesto de plano la sanción, ya que, ante la Sala de Gobierno, por la vía del recurso de alzada, pudo formular las alegaciones que tuvo por convenientes en defensa de su derecho. La sanción impuesta al recurrente constituye una manifestación llamada "policía de estrados»; esta potestad de la Presidencia de los Tribunales en los juicios orales se concibe como un instrumento indispensable para asegurar la integridad y correcto desarrollo del proceso (art. 24.1 C.E.), obtener el cumplimiento de las obligaciones procesales de las partes de probidad y de buena fe (art. 24.2 C.E.). Todos los anteriores son fines constitucionalmente legítimos, a cuyo servicio se pone dicha libertad de ordenación (potestad de ordenación), y la misma trascendencia de los fines perseguidos puede requerir que, en ocasiones, se ejerza ésta y se impongan las sanciones que lleve aparejada su inobservancia de forma inmediata en el tiempo de la infracción. Por ello, en casos como el presente - añade el Tribunal Constitucional-, las alegaciones que en su defensa puede hacer 1a parte deben realizarse en vías de recurso, a posteriori sin que el carácter

\footnotetext{
${ }^{56}$ E. GarCía de EnTERRÍA, «La significación de las libertades públicas en el Derecho administrativo», en Sumario de Derechos Humanos, 1981, pp. 113 y sigs. E. GarCía DE EnTERRía, Sobre la situación de la justicia administrativa y su reforma», en Otrosi, Revista del Ilustre Colegio de Abogados de Madrid, 1995, p. 5.

${ }^{57}$ I. LASAgabaster HeRRARTE, «Derechos fundamentales y personas jurídicas en el Derecho público». En Estudios sobre la Constitución española, Ed. Civitas, Madrid, 1991, pp. 651 y sigs. y L. Martín-Retortillo Baquer, «Eficacia y garantía de los derechos fundamentales». En Estudios sobre la Constitución española, Ed. Civitas, Madrid, 1991, pp. 588 y sigs.
} 
pospuesto del derecho a la defensa suponga merma de los derechos contenidos en el artículo 24 C.E. ${ }^{58}$.

El reconocimiento constitucional del derecho a la tutela judicial que asiste a todos los ciudadanos (art. 24.1 C.E.), y el carácter esencial que para el funcionamiento de la Justicia revista la figura del Abogado, dispone —y así se ha recogido en 1a legalidad ordinaria (art. 437.1 LOPJ)— que en su actuación ante los Jueces y Tribunales los Abogados sean libres e independientes, gozando de los derechos inherentes a la dignidad de su función. Por lo que deberán ser amparados por aquellos en su libertad de expresión y defensa. La libertad de expresión del Abogado en el ejercicio de la actividad de defensa es una manifestación cualificada del derecho reconocido en el artículo 20 de la Constitución, porque se encuentra vinculada con carácter inescindible a los derechos de defensa de la parte (art. 24 C.E.) y al adecuado funcionamiento de los órganos jurisdiccionales en el cumplimiento del propio y fundamental papel que la Constitución les atribuye ${ }^{59}$.

Me interesa ahora retomar el hilo de mi exposición y del contenido de la resolución del Tribunal Constitucional ${ }^{60}$. Se sigue afirmando que el ejercicio de la libertad de expresión en el seno del proceso judicial por los Letrados de las partes, en el desempeño de sus funciones de asistencia técnica, posee una singular cualificación, al estar ligado estrechamente a la efectividad de los derechos de defensa del artículo 24 C.E. En efecto, como se ha dicho en la STC 157/1996 ${ }^{61}$, la relevancia constitucional de esa peculiar libertad de expresión deviene su conexión instrumental con el derecho fundamental de las partes en el proceso a la defensa y asistencia letrada, que vienen reconocidas en el artículo 24.1 C.E., de modo que bien puede decirse que «el derecho de los ciudadanos a la defensa y asistencia de Letrado implica un derecho a una defensa libremente expresada». Sigue diciendo dicha sentencia que «la libertad de expresión, por tanto, del Abogado en el ejercicio de su función de defensa, debe ser concebida como un

58 J. Almagro Nosete, «La prohibición constitución de indefensión», en Poder Judicial, Madrid, núm. 4/1989.

${ }^{59}$ A. DE Asís RoIG, «Plenitud del control judicial en la fase de apelación y calificación de infracciones administrativas», Poder Judicial núm. 6/1987; J. García ToRres, «Reflexiones sobre la fuerza vinculante de los derechos fundamentales», Poder Judicial núm. 10/1988 y J. García TORRes y A. Jiménez Blanco, Derechos fundamentales y eficacia entre particulares, Ed. Civitas, Madrid, 1986.

${ }^{60}$ STC 113/2000, de 5 de mayo (Suplemento BOE núm. 136, de 7 de junio). Vid. también STC $226 / 2001$, de 29 de noviembre.

${ }^{61} \mathrm{FJ} 5^{\circ}$. 
supuesto particularmente cualificado de esa libertad fundamental», resultando «una libertad de expresión reforzada por su inmediata conexión a la efectividad de otro derecho fundamental, el derecho a la defensa del art. 24.2 C.E.». Es éste, en definitiva, el espíritu que late en el artículo 437.1 LOPJ cuando dispone que «en su actuación ante los Juzgados y Tribunales los Abogados son libres e independientes, se ajustarán al principio de buena fe, gozarán de los derechos inherentes a la dignidad de la función y serán amparados por aquéllos en su libertad de expresión y defensa». Tales circunstancias concurren precisamente en el supuesto que se conoce en el presente recurso de amparo. Ciertamente, la condena penal se fundamentó en especial no en el recurso de reforma formulado en el proceso correspondiente sino en el escrito dirigido al Fiscal Jefe del Tribunal Superior de Justicia de Andalucía. Mas ello no obsta a la conclusión expresada pues dicho escrito, tanto por su contenido y finalidad, ya expuestos anteriormente, como por la condición profesional en que actuaba su autor (Abogado defensor de uno de los imputados en el proceso por delito), no puede desvincularse del proceso penal de referencia, en virtud del cual se produjo y sólo en virtud del cual tiene sentido ${ }^{62}$.

Luego abunda el Tribunal (F.J. 5. ${ }^{\circ}$ ) que la corrección disciplinaria de los Abogados que prevé el artículo 448 LOPJ constituye un reforzamiento de la defensa que éstos tienen encomendada, siendo preferible aplicar esta vía que la vía penal (SSTC 38/1988, 92/1995 y 157/1996).

En el F.J. $6 .^{\circ}$ concluye el TC que ha de otorgarse el amparo solicitado (STC 205/1994 que también cita) afirmando que las expresiones vertidas no pueden calificarse formalmente de injuriosas o vejatorias ni para el Fiscal interviniente en la causa ni para ninguna otra autoridad o persona que hubiese tenido intervención en ésta. También justifica la sentencia que el escrito haya sido dirigido al Fiscal Jefe pues ello tiene su base en el artículo 25 del Estatuto del Ministerio Fiscal ${ }^{63}$.

Antes de concluir nuestro trabajo, hay que destacar la conexión que existe entre los artículos 14, 20 y 24, en relación con el 53.2 C.E. y los artículos 205 y 634 de la Ley 10/1995, de 23 de noviembre, del Código penal (sin olvidar la Ley Orgánica de protección del honor la intimidad y la propia imagen de 1982) no estando de más repetir en este punto que varias de las garantías tipificadas en el artículo 24.2 — por ejemplo, el propio dere-

\footnotetext{
62 El Estatuto Orgánico del Ministerio Fiscal fue aprobado por Real Decreto 507/1981, de 30 de diciembre (BOE de 13 de enero de 1982).

${ }^{63}$ F. Garrido Falla, Comentarios a la Constitución española, Madrid, 1985. Vid. también el Estatuto Orgánico del Ministerio Fiscal.
} 
cho a defenderse, así como los derechos a ser debidamente informado de la acusación, a utilizar medios de prueba y a la presunción de inocencia-, resultan de directa aplicación en los procesos o procedimientos administrativos sancionadores, que, de igual modo que los procesos penales, no son sino manifestaciones paradigmáticas de la potestad punitiva del Estado. Por otro lado, entre las variadas manifestaciones del derecho a la asistencia y defensa de letrado puede hacerse mención de las siguientes: con carácter general, el derecho de defensa supone ${ }^{64}$ que la persona afectada por un procedimiento debe ser oída no sólo en el conjunto global del propio procedimiento, sino también en cada una de sus fases que pueda repercutir en los derechos e intereses legítimos de la persona; el acusado tiene derecho a defenderse por sí mismo ${ }^{65}$, a defenderse mediante asistencia letrada a su elección, y en ciertos supuestos y cuando concurran determinadas circunstancias, a recibir asistencia letrada gratuita; la simple posibilidad de presentar alegaciones y de presentar pruebas es suficiente para que el derecho se considere respetado — de aquí que, como se ha dicho autorizadamente, es constitucional el juicio en rebeldía dirigido contra quien se le ha notificado la existencia de un proceso (es fundamental, a este respecto, que la notificación cumpla las debidas garantías, mediante técnicas como el emplazamiento personal, que ha sido objeto de especial tratamiento) ${ }^{66}$ y no se ha personado en dicho proceso-; el órgano judicial tiene el deber de evitar desequilibrios entre las respectivas posiciones procesales de las partes, así como limitaciones en la defensa susceptibles de producir indefensión; y, finalmente, la defensa debe extenderse —en palabras de PIÑEL LóPEZ ${ }^{67}$ — «tanto a los hechos como a los fundamentos jurídicos de la controversia judicial» ${ }^{68}$.

Y, en cuanto al derecho a la presunción de inocencia, la jurisprudencia constitucional ha señalado como notas delimitadoras de su contenido, entre otras, las siguientes: a) para condenar o sancionar debe tenerse la certeza de la culpabilidad con base en la valoración de una prueba exis-

\footnotetext{
${ }^{64}$ J.M. ${ }^{a}$ Serrano Alberca, «Comentarios sobre los arts. 24 y 121 C.E.», en Comentarios a la Constitución española, Madrid, 1985.

${ }^{65}$ Del derecho de autodefensa se hablará enseguida.

${ }^{66} \mathrm{~J}$. VACAS García-Alós, El derecho a la tutela judicial efectiva en lo contencioso-administrativo, La Ley, Madrid, 1996.

${ }^{67}$ E. PIÑ̃L LóPEZ, «El derecho a la tutela judicial efectiva por los Tribunales de Justicia», Revista del Poder Judicial, Vol. I, Madrid, 1983.

${ }^{68}$ J. VACAS GARCíA-Alós, El derecho a la tutela judicial efectiva en lo contencioso-administrativo, Ed. La Ley, Madrid, 1996 y F.J. JimÉNez LeChUGA, La responsabilidad patrimonial de los poderes públicos en el Derecho español (una visión de conjunto), Ed. Marcial Pons, Madrid, 1999.
} 
tente llevada al proceso con las debidas garantías, b) la valoración de las pruebas es competencia exclusiva del órgano juzgador, c) la carga de la actividad probatoria pesa sobre los acusadores y no existe nunca carga del acusado sobre la presunción de inocencia, d) el derecho a la presunción de inocencia no se opone a que la convicción judicial en un proceso penal pueda formularse sobre la base de una prueba indiciaria, pero para que ésta pueda desvirtuar dicha presunción deberá ratificar las siguientes garantías o exigencias constitucional (de un lado, los indicios han de ser plenamente probados y no pueden ser meras sospechas, y, el órgano judicial debe explicitar el razonamiento, en virtud del cual, partiendo de los indicios probados, ha llegado a la conclusión de que el procesado ha realizado la conducta tipifica como delito), con lo que se está dando también cumplimiento a la necesaria motivación de las resoluciones judiciales y a la debida fundamentación jurídica de éstas.

$\mathrm{Y}$, en cuanto a las dilaciones indebidas, ha señalado con acierto F. Sото NiETo que tampoco una justicia expeditiva, impeditiva e improvisada y apresurada es el canon ideal que demanda la ciudadanía y los justiciables. La dispensación de justicia tiene mucho de reflexión y análisis. Las ideas surgen y se reafirmen con el estudio, 1a advertencia y la confrontación. Una de las manifestaciones de la jurisprudencia judicial (mejor sería decir prudencia judicial) consiste en la cuidadosa percepción y examen de las pretensiones de las partes, de los informes que las sustentan, de la cimentación jurídica que las refrenda. Eso requiere un tiempo razonable que no debe prolongarse, pero tampoco cercenarse en desmesura ${ }^{69}$.

\section{CONCLUSIONES}

Este estudio no tiene otras pretensiones que las que recogen sus propios epígrafes. Es palmario, por tanto, que no nos hemos ocupado del ejercicio de las profesiones liberales en general en nuestro país ni tampoco lo hemos hecho con la detención y extensión que esto requiere en el caso del ejercicio de la Abogacía en España ${ }^{70}$. Este estudio está por hacer

\footnotetext{
${ }^{69}$ F. Sото NIETO, «Jueces y Abogados. Miscelánea sobre sus condiciones y deberes», La Ley núm. 3878/1995.

${ }^{70}$ Desde aquí invitaría a que un joven doctorando se ocupase de esto y me lo comunicase ya que es un asunto sobre el que no existen estudios completos pese a la importancia de la institución. Sí los hay, en cambio, y muy buenos, sobre la Abogacía del Estado. Vid. L. Martín-Retortillo BAQUER, «La defensa en Derecho de las Administraciones Públicas», RAP núm. 121/1990. De este mismo autor puede leerse una preciosa monografía en Civitas, aunque no recuerdo si es de Sebastián o de Lorenzo.
} 
y es obligación de quien esto escribe pasar el testigo a otros porque la trascendencia del tema sin duda requiere de una investigación más amplia y rigurosa que recoja los antecedentes históricos de la profesión así como su situación actual ${ }^{71}$. Parece, por el momento claro, de lo expuesto, lo siguiente:

Primero.- Existen unos elementos axiológicos o conceptos metajurídicos de imposible o difícil normación que son los derechos humanos, forma moderna del viejo iusnaturalismo, pero que la conciencia social hace suyos y que, en consecuencia, deben regir en una comunidad o grupo social avanzado. Estos derechos humanos y esos valores superiores del ordenamiento jurídico han sido recogidos por distintas convenciones inter-

\footnotetext{
${ }^{71}$ Esta pequeña contribución al estudio de esta apasionante profesión me surgió de conversaciones con los afectados y mi amistad con alguno de ellos (don Luis Portero García y don Jorge Aguilera González, por ejemplo). Es posible que este estudio no guste a mi amigo el profesor Alfredo Gallego Anabitarte. Y digo esto porque últimamente lo encuentro algo irascible e inquieto y siempre ve «descripciones» donde a veces hay verdaderas aportaciones al estudio de instituciones jurídicas verdaderamente notables. Y tengo que decir todavía algo más en relación con mi amigo Alfredo Gallego Anabitarte. Aunque es sabido que yo participo de la concepción del Derecho que él sostiene e incluso somos germanófilos —él mejor conocedor de aquel ordenamiento jurídico que yo mismo, aunque no sé si del Derecho francés también lo será tanto-, es evidente que sus tesis pueden encaminarse por senderos inciertos e incluso ignotos, que incluso pueden conducir a un cul de sac. Y digo esto porque esta tesis, con independencia del método jurídico que se siga, pueda conducir a una jurisprudencia de conceptos (Begriffsjurisprudenz) que podemos definir en alemán como Begriffsjurisprudenz als eine Methode der Rechtsanwendung geht von dem Grund gedanken aus, daB die Rechtsordnung in aienem geschlossenen System von Begriffen besteht, das mit den Methode des lögischen Deduktion ausgelegt wird. Supongo que mi amigo comprenderá bien lo que quiero decir. También debo decir que yo prefiero las tesis elaboradas por Rudolph von IHERING y sobre la jurisprudencia de intereses (Interessenjurisprudenz) que no son posiciones o tesis análogas como pudiera pensarse a primera vista. No diré nada más en este lugar. También recuerdo que Friedrich Nietzsche decía en uno de sus conocidos aforismos que era su ambición decir en diez frases todo lo que los demás dicen en un libro, o incluso todo lo que los demás no dicen en un libro. Ni Alfredo Gallego Anabitarte ni yo mismo hemos llegado aún a ese sincretismo nietzscheano por así decirlo. Sí me parece deseable decir algo último en relación con el comentario que yo hice a los libros Lecciones..., de A. Gallego Anabitarte, A. Menéndez Rexach, et alli (Revista de Estudios Locales (CUNAL) núm. 53/2002) y lo que acabo de afirmar en la nota presente. En realidad, las tesis de A. Gallego Anabitarte y la metodología empleada en la exposición de la materia son originales y tienen un punto de partida diferente al de la doctrina española mayoritaria o dominante. Toda esta concepción del Derecho (del Derecho administrativo, en particular) la suscribo enteramente. Ahora bien, no es ello óbice, no obstante, para que yo tenga el derecho a la discrepancia - que lo tengo, sin duda-, pero no en lo esencial, sino en lo accidental, naturalmente. Lo que he querido decir es que, dada la peculiaridad y «rareza» en la exposición de la disciplina por el profesor de la Universidad Autónoma de Madrid, resulte algo difícil la comprensión («aprehensión») de los conceptos que tan brillantemente expone el citado profesor y en lo que le secundan sus discípulos, como el mismo dice - yo soy un buen amigo porque lo de discípulo me gusta bien poco- - Hay un abismo a colegir de todo lo que llevo dicho - y esto me parece que se ha hecho ciertamente- que piense yo ni siquiera remotamente que lo que mi amigo hace sea mera «jurisprudencia de conceptos», antes al contrario, creo que entiende el Derecho en profundidad y desde bases muy sólidas. No diré más.
} 
nacionales y han adquirido carta de naturaleza en nuestra Carta Magna (arts. 1,9 y 10 C.E.).

Segundo.- Los derechos fundamentales y las libertades públicas son directamente exigibles e invocables ante cualquier autoridad o particular y han sido reconocidos constitucionalmente, siendo algunos de ellos, reforzados por un procedimiento preferente y sumario para su efectiva realización (arts. 14 a 30.2 y 53.2 C.E.). La casuística y los problemas que la configuración doctrinal de los derechos fundamentales se plantea ha sido estudiada con cierto detalle por la doctrina española, como habrá podido comprobarse a lo largo de estas páginas.

Tercero.- Para mí, no así para otro sector doctrinal, los derechos fundamentales son los comprendidos en los artículos 14 a 33 -otros admiten incluso hasta el art. 38- de la Constitución, no pudiéndose tener por tales al resto que sí son, empero, principios rectores de la política económica y social del Estado conforme previene la propia Constitución.

Cuarto.- Resulta, por lo demás, evidente, que existe un doble aspecto subjetivo-positivo, es decir, subjetivo-objetivo desde el que pueden y deben estudiarse los derechos fundamentales. Ello quiere decir que el individuo debe tener derecho al respeto por el Estado de sus derechos fundamentales. Pero, es evidente, también, que el ejercicio de estos derechos fundamentales por el individuo deben ser también respetados y tener efectos frente a terceros. Es lo que la doctrina alemana llama Drittwirkung ${ }^{72}$.

Quinto.- En Alemania, hace ya bastantes años, algunos juristas de prestigio y el propio Tribunal Constitucional alemán se hicieron pronto eco de la defensa frente al legislador ordinario y a terceros del respeto a determinadas instituciones jurídicas, distintas de los derechos fundamentales, que deberían respetarse en «términos que su regulación las hiciese recognoscibles a los demás», como también ha puesto de relieve muy recientemente el propio Tribunal Constitucional español. Aquí se encuen-

\footnotetext{
72 Vid. A. Gallego Anabitarte, op. cit. Vid. también STC 185/2002, de 14 de octubre (BOE núm. 271 , de $12-11$ ) y SSTC 52/2002, de 25 de febrero, 83/2002, de 24 de abril, 99/2002, de 6 de junio y 120/2002, de 20 de mayo. También SSTC 202/2002, de 26 de octubre (BOE núm. 278, de 2011) y 180/1985, de 19 de diciembre. Cfr. además, sin que ello tenga que ser necesariamente inoportuno, A. CAmus, El extranjero, Ed. El País, Madrid, 2002; J.P. SARTRE, La náusea, Ed. El País, Madrid, 2002; H. Hesse, El lobo estepario, Ed. El País, Madrid, 2002 y A. Malraux, La esperan$z a$, Ed. El País, Madrid, 2002. Resulta curioso observar aquí que la complejidad y complicaciones del lenguaje en el escritor irlandés James Joyce se observan también en muchas sentencias de nuestros Tribunales. Lo que en el escritor irlandés es un mérito indiscutible, es, por otras razones, asaz censurable en el caso de la justicia. Al menos a mí eso es lo que me parece. James Joyce (1882-1941).
} 
tra claramente la garantía de la autonomía local, la opinión pública, la libertad de cátedra o la institución misma de los Colegios Profesionales (art. 36 C.E).

Sexto.- También puede dejarse sentado aquí que el ejercicio de la Abogacía en España se encuentra respaldado desde los ámbitos que han sido analizados. Más concretamente. Hay que poner en conexión los artículos 14, 20, 24 y 36 C.E. y las normas que regulan estos Colegios Profesionales así como su Ley de 13 de febrero de 1974 (modificada posteriormente).

Por ello, de una parte, en el libre e independiente ejercicio de su profesión, los Abogados no tendrán impedimento ni cortapisa alguna, teniendo como únicos límites los Códigos deontológicos y el respeto a los derechos de los demás.

En este sentido, el derecho de defensa constituye para los Abogados uno de los derechos que componen el haz en que se integra su Estatuto — quizás el más destacado- pero disponen de otros muchos. No puede afirmarse en puridad que sea éste un derecho fundamental de los Abogados, pero sí un instituto que puede y debe beneficiarse de las garantías institucionales tal y como las ha definido hasta el momento el Tribunal Constitucional español.

Esto que antecede es independiente del supuesto de autodefensa. En este último caso, evidentemente, estamos en presencia del derecho de defensa como un derecho fundamental. Pero ya no lo estamos por la sola invocación del derecho a 1a libertad de expresión, tal y como lo ha definido el Tribunal Constitucional español, sino ante el otro derecho fundamental a la tutela judicial efectiva del artículo 24.1 C.E. Así, se trataría de un doble derecho fundamental y reforzado.

Séptimo.- Parece también claro que cuando nos encontramos en presencia de varios derechos fundamentales, habrán de ponderarse debidamente los intereses en juego para acertar a saber cuál prevalecerá en caso de conflicto. En esto el Tribunal Constitucional y la doctrina española son unánimes.

Octavo.- - Los Abogados no deberían ser sancionados sino en estrados o por los medios que prevén los propios Colegios Profesionales en su actuación ente Jueces y Tribunales. Aunque esto no puede sostenerse lege data, parece deseable también que cuando las diligencias penales previas conduzcan a un juicio verbal de faltas, por infracción en la forma que 
fuere, del artículo 634 del Código penal, sería deseable que tales actuaciones tuviesen sede colegial y no jurisdiccional.

Por lo demás, también es patente que cuando los abogados, con ocasión del ejercicio de su profesión, tengan que emitir juicios de valor o de sana critica, tendrán toda la libertad para hacerlo si se trata de cualquier autoridad o sus agentes, en cuanto se refieran al ejercicio de la misma, con el respeto únicamente a las normas de convivencia y de respeto debido a todos los poderes públicos. Así, hasta cualquier resolución judicial puede y debe ser criticada por cualquier ciudadano u operador jurídico sin más límites que su actamiento y respeto.

La STC 113/2000, de 5 de mayo, aquí analizada, es ejemplar, aunque ya existían precedentes. Seguramente los Jueces de Instrucción habrán de tener mucho cuidado en los llamados juicios de faltas porque en la mayoría de los casos, los ciudadanos, como hayan criticado educadamente a cualquier autoridad o sus agentes, serán absueltos sin duda alguna con la mera invocación de esta preciosa, aunque simple, decisión del Tribunal Constitucional español. 